\title{
e-Phaïstos
}

e-Phaïstos Revue d'histoire des techniques / Journal of the history of technology

VIII-2 | 2020

Aviation : émergence d'un complexe technique, 1900-1930

\section{Asturias: Technology, Industry and History of Science}

\section{Towards a Socio-Cultural History}

Les Asturies : Technologie, industrie et histoire des sciences. Vers une histoire socioculturelle

Jorge Uría González

\section{(2) OpenEdition}

\section{Journals}

\section{Electronic version}

URL: https://journals.openedition.org/ephaistos/8207

DOI: 10.4000/ephaistos.8207

ISSN: 2552-0741

\section{Publisher}

IHMC - Institut d'histoire moderne et contemporaine (UMR 8066)

\section{Electronic reference}

Jorge Uría González, "Asturias: Technology, Industry and History of Science ", e-Phaïstos [Online], VIII-2 | 2020, Online since 27 October 2020, connection on 18 September 2021. URL: http:// journals.openedition.org/ephaistos/8207 ; DOI: https://doi.org/10.4000/ephaistos.8207

This text was automatically generated on 18 September 2021

Tous droits réservés 


\title{
Asturias: Technology, Industry and History of Science
}

\author{
Towards a Socio-Cultural History \\ Les Asturies: Technologie, industrie et histoire des sciences. Vers une histoire \\ socioculturelle
}

Jorge Uría González

1 At first sight, research on technological-industrial history and its physical vestiges enjoyed excellent starting conditions in Asturias for its development within institutions. This area of Spain did indeed have a more than considerable industrial and technological heritage within the whole of the Iberian Peninsula - given that it had been one of its most dynamic points since the early days of industrialisation. In fact, at the end of the 18th century, initial attempts in this direction had already begun with the commissioning of the first coal mines and blast furnaces for steel production.

2 Throughout the 19th century, and in particular during the last third of it, this process would accelerate considerably, while industrial development and diversification grew. Until the general expansion of Spain's economic development extended the process to large parts of the country, well into the 20th century, Asturias' focus of industrialisation would in fact, along with the Basque Country and Catalonia, constitute one of the most efficient vectors of Spanish industrialisation and one of its indispensable historical points of reference.

3 Awareness of the value of this rich heritage and its gradual discovery by the academic world was, in this sense, something that had to arrive as an almost natural result of this state of affairs. Somewhat in parallel to what happened elsewhere, the historiographic and interpretative start of its study followed a chronology similar to that of other Spanish regions. In spite of the precedents that can be traced back to the 1960s, it was then - as was understood from the 70s and $80 \mathrm{~s}$ - that the real disciplinary roots of this type of study began.

4 The most academically significant signs of curiosity about this important heritage would follow economic and geographic studies, which are undoubtedly most sensitive 
to the important mark left by the industrial revolution on growth processes, as well as the radical transformations induced among the landscapes and urban fabric of these facilities. At that time, of course, Asturias benefited from the general reflection of economic historians when sketching out the region's role within the Spanish model of industrial growth, whose originality or «deviations » were widely discussed during these years, following Jordi Nadal's provocative thesis about the failure of the industrial revolution in Spain due to it not aligning with the British model of industrial growth.

\section{Geographical studies}

5 However, the influence of geographical studies would be more decisive. Less susceptible to the elegant discussion about the great models of growth, or the complexities of the major economic powers, geographers showed a much sharper perception, on the other hand, towards the morphological aspects and physical embodiments of the industrial transformations; and in fact we should not forget that, linked to this type of research, exhaustive lists of the industrial equipment would emerge - and even the first clues of their rigorous inventory. The geographical studies also had quite favourable additional circumstances in Asturias. The establishment of an excellent school of geographers at the University of Oviedo under the direction of Francisco Quirós Linares, who joined this institution in 1970, was already a reality at that time. The growth of the Geography Department, created as an administrative unit from 1976, would gather strength over the following years. This was a period of growth of the universities and a "massification » of enrolments; students of Philosophy and Letters, numbering 351 in 1961, had increased five-fold to 1795 ten years later in 1972. At the same time, so did the teaching staff, which tripled in number over the period 1965-75 to 574 teachers.

6 Some of the projects worked on during these years on regional urban development or industrial geography, opened the way in this regard; and so it was with research into Gijón carried out by Ramón María Alvargonzález and Moisés Llordén (1977 and 1978 respectively) and in particular by Guillermo Morales (1976) on the geographical dimensions of Asturias' industrial space. The work done by this team of researchers, on the other hand, was stabilised, and gained in continuity and a more solid institutional basis following the creation of its journal, Ería, the first issue of which arrived in 1980.

7 Naturally, the journal covered many more aspects than industrial geography, urban planning and descriptions or study of the landscape's traces of human activity in the industrial territory. However, its work in this field would be very valuable in the years to come - even more so if we consider that, despite the fact that it included articles whose subject matter went beyond the strictly regional sphere, it focused above all on the Asturian reality to which it was closest. This was an ambitious, versatile publishing platform open to multiple stimuli. Far from limiting itself to a simple geographical description or the more conventional content seen in this discipline, it was open to the pedagogical innovations in this field. It took on debates about epistemology and geographical theory. It included sporadic excursions into geopolitics. And it added a few articles on history and geographical historiography that were of interest. During its first decade, up until 1990, its 23 issues devoted a significant proportion of their contents (approximately 45\%) to developing structural and basic issues within a 
discipline that was not yet established in the region. It is not surprising, therefore, that articles on geomorphology and physical geography can be found within its pages, as well as a rural geography that is indispensable for providing coherence to the essence of the surrounding regions' landscape.

But more important than all this, for the purposes of the topic under discussion, would be the fact that more than one third of the articles (approximately 35\%) were devoted to topics which, as has already been said, were directly related to the treatment of the material remains of industrial and service facilities associated with the deployment of industrialisation; and in particular, with the urban geography and the port facilities (an aspect that these geographers paid great attention to), and above all with an industrial geography that was a pioneer in many of the strategic sectors that, over the following years, were to focus the attention of industrial archaeologists. Thus, successive articles would appear over those years that advanced the essential elements of the development of the electricity and railway networks, and the consequences of the industrialising policies of the Poles on development sponsored by the Franco regime; or the characteristics of rural industrialisation, the consequences of industrial decentralisation and its impact on the relations between countryside and city, in addition to the expansion of the food industry.

The decade also opened up a reflection in the magazine that, over time, would become almost an obsession in social, historical or economic debates within Asturias: the impact of industrial reconversion and its effects, of all kinds, including its environmental footprint - which was even explored historically - or the obvious effects it had on territorial planning. Coal mining - historically dominant in Asturias' industrial structure along with the iron and steel industries - was certainly the most recurrent matter given the evidence of its problems, once a slow decline had begun since Franco's developmentalist policies had cornered the model of energy autarchy, and competition from lower-priced foreign coal began to be allowed. The geographical study of Asturias' mining basins, the footprint of the paternalistic business policies of the industry throughout its previous history of two centuries (which were extensively studied by José Sierra : Sierra 1990), and of course the study of the processes of decline of the traditional mining-steel areas, were thus imperative tasks.

The 90s were, in any case, a period of evident maturation of all these themes, which can be easily seen within the contents of this journal - a true indicator of the general progress of industrial heritage studies - but equally evident in a fair few other signs. As regards the geographical publication, in the new decade leading up to 2000, the journal's 27 issues naturally continued to pay outstanding attention to basic issues such as geomorphology, cartography and physical geography (17\% of its content), and the magazine did not neglect paying unavoidable attention to agricultural activities, landscapes and planning of rural areas and other activities - such as those of the fishing industry (another $20 \%$ of the articles). Above all, however, the journal continued to be a porous publication, open to multiple stimuli and capable of absorbing frontier fields that once again made it a versatile, imaginative publication capable of proposing and disseminating methodological or thematic innovations of all kinds.

11 Agricultural associationism, the organisation of industrial work, geopolitics and territorial conflicts, historical or historiographical aspects and geographical theory or methodology, thus formed part of a heterogeneous and miscellaneous chapter of topics which, as a whole, represented almost $30 \%$ of its content; and which, taken overall, 
represented considerable flexibility and openness within institutional trends that generally - and within the scope of the university - tended more towards hyperspecialisation and disciplinary isolation. Some of these themes also delved into industries like tourism that would later give rise to a peculiar archaeology of the leisure industries that had hardly been developed at the time. In fact, the articles related to spas, ecotourism and the sustainability of its activities, appeared highlighted within its contents. And aspects such as the recovery and redefinition of the uses of historical centres even drew the attention of one of its few special issues (in issue 47, 1998).

But above all, and this is perhaps the most interesting thing now, the publication to which we refer continued to pay attention to issues close to industrial and urban heritage via subjects that had already been noted in its first decade. In fact, articles related to geography and urban planning, as well as those directly focused on industrial and economic geography, still accounted for $32 \%$ of its content. In fact, and without disregarding the contributions made from the ever-interesting chapter of geography and urban facilities, industrial and economic geography once again provided materials and approaches that, from our point of view, were highly suggestive. Over these years, the railway communications sector was further developed, for instance, by examining the facilities and activities carried out on the Spanish National Railway Network, by claiming the role played by the former installations of the Robla to León Railway, and by examining the impact of high speed train infrastructures in France with a view to assessing their derivations in Spain's own high-speed network.

Some of the transformations brought about by the disappearance of old railway lines immersed in the urban fabric and which led to significant changes in its network and ambitious urban development operations characteristic of that time, were also given their platform for study and publicity by this magazine - as in the case of the operations that opened in Madrid and defended the creation of a new "green grid", or those started in Oviedo for the development of its " green belt ». There was also no lack of studies into industrial activities within urban centres, their productive and spatial reorientation, and their impact on the service sector. Between one thing and the other/ among other things, it also informed about the options for study opened by consulting on unexplored documentary sources, river itineraries, explored the historical impact of the forges on the forest areas of Cantabria, and assumed the defence of the institutional protection and cataloguing of Asturias' industrial complexes such as that of the Samuño Valley.

In short, deindustrialisation and alternative reindustrialisation projects also occupied the attention of geographers, making them prominent participants in a debate that shook the social sciences and sociological and journalistic disputes in a former industrialised region like Asturias, where the scars from the loss and abandonment of industrial equipment and general decline in economic activity were already visible. The discussion on the taxonomy of deindustrialised areas, and in particular their characterisation from a sociological point of view, was gaining theoretical importance with the immersion in the debate of regional sociologists who, as in the case of Rodolfo Gutiérrez (among others) were insistently reflecting on the processes of industrial decline in areas of old industrialisation, starting from the sociological analysis of Asturias and, in particular, of depressed mining and steel areas (Gutiérrez 2009). 

continue over the following decade, and contributing interesting approaches or launching new themes; and proof of this would be the appearance of special editions such as the one by Faustino Suárez Antuña on the organisation of Asturias' coal areas (Suárez Antuña 2005). But the most important transformation in the field of studies and projects on industrial heritage would come from the dispersion, diversification and significant increase of its volume in absolute terms, until it went beyond the strictly university field and spilled into a more extensive network of associations, study groups or publications - a trend that was more pronounced with the exponential development that social networks and the internet would create from the end of the nineties.

For the region, however, the processes of industrial reconversion had meant the beginning of a marked identity crisis - once the process of industrial closures started and the evidence of premises already empty of all activity was confronted. These were years not only of constant debate in the press about the social effects and all kinds of other effects of the economic slowdown, but also of public awareness of the danger of the physical disappearance of the emblematic vestiges of industrialisation. Some of the most characteristic working sectors linked to these activities claimed pride in their trade, organised themselves into associations of retired employees or encouraged private collections (which remain poorly studied) of old industrial tools such as old mine lamps - the latter becoming icons of a working activity appreciated and even seen as heroic.

\section{The creation and development of INCUNA}

The setting up, in 1999, of the association INCUNA (Industry, Culture, Nature), which was designed to be an organisation for the study of industrial archaeology and Asturian cultural and natural heritage, driven by Miguel Ángel Álvarez Areces, economist and former head of studies and Director of Heritage for state mining company HUNOSA must certainly be considered as part of this highly varied set of circumstances. The work of the association since then has been very important. Thanks to the activism of INCUNA's chairman and his excellent international contacts - given that he is also chairs the Spanish Section of The International Committee for the Conservation of the Industrial Heritage (TICCIH Spain), INCUNA has become a powerful vector that facilitates the convergence of a very wide range of organisations, academics, scholars and fans of archaeology and industrial heritage not only in the Asturian region, but also beyond. As stated in its institutional propaganda, the Association's objectives were as broad as they were ambitious. The organisation proposed to take on responsibility in general «for defending, recovering and disseminating the historical heritage of industry ", as well as for promoting its study and the setting up of museums and interpretation centres capable of fostering and hosting all these tasks.

Its goals were also to disseminate this rich heritage by encouraging « activities related to cultural and industrial tourism, itineraries » or other types of educational activities related to industrial heritage; as well as to cooperate in promoting local and regional socio-economic and cultural development by taking advantage of any industrial or technological vestiges that are most susceptible to it. It also took on the goal of defending and promoting all types of activity that could propagate the history of technology, that of productive or social devices, and architecture and the arts related

e-Phaïstos, VIII-2 | 2020 
to tangible and intangible or immaterial industrial heritage. In the area of science, INCUNA expressed its will to start agreements with companies, research organisations and public authorities; arrange conferences, seminars, courses and all kinds of meetings of a scientific nature or aimed at defending industrial heritage; as well as promoting the publication of books, magazines, multimedia publications and any other audio-visual procedure aimed at meeting the association's objectives.

It is true that the goals set by the association were ambitious, and that its wording seemed to be a recitation of the good intentions that used to be set out when many of these societies were set up - the fate of which, in many cases, was to crawl languidly or simply fade away after a while. This, however, was not the case with INCUNA. Since it was set up almost twenty years ago, the organisation has been able to fulfil a significant part of its initial intentions with scientific dignity and with highly visible results in terms of preserving, cataloguing and disseminating heritage. Its campaigns to publicising industrial sites and the activities in defence of their premises and aspects of their landscapes; its efforts to have this included in Asturias' Inventory of Cultural Heritage or Municipal Urban Planning Catalogues through direct management, or by using resources such as Twitter, Facebook, and the " news " section published monthly from the website... all these ensure that it fully fulfils its purpose.

In addition, of course, there are specific proposals in this regard - such as those made in publications like Patrimonio industrial de Asturias: 33 propuestas de industria, cultura y naturaleza (Asturias' Industrial Heritage: 33 Proposals for Industry, Culture and Nature), 2009. In terms of raising awareness, the organisation has directly taken part in creating a number of industrial tourism itineraries at international and national levels. Three of these are in Asturias and are related to military industry, agro-food heritage, and maritime, fluvial and fishing heritage. It has also encouraged digital platform projects in support of Spain's mining landscape heritage (mineriaypaisaje.com). The heritage workshops held in locations such as Soria, Legazpi (Madrid), Segovia, San Cebrián de Mudá and Vallejo de Orbó (Palencia) and Ponferrada (León) must also be mentioned, as should the online courses held between 2012 and 2014 on Planning of Heritage Spaces.

21 Surely, however, the greater part of research excellence is due to its publications and annual INCUNA conferences (jornadas). After its initial launch when it focused on local issues, the conferences were quickly opened up to national and international collaborations, as well as to themes with broad ambition and the purpose of renewing. of course, part of its focus was, as required, on describing and handling area of heritage that, although evidently present elsewhere (as recognised in the materials presented during its sessions) nevertheless featured strongly in the industrial landscapes of Asturias. It is therefore understandable that the industrial premises and their impact on the collective memory, and the metal industry heritage, had their rightful place in the conferences' programme. However, it was evident that the concern for these themes was always in line with that shown by many others - such as industrial heritage linked to war, themes related to maritime, river or fishing areas, or in more general terms with architecture, engineering and water cultures as well as with the attention paid to the vestiges of the film industry.

To a degree, it was inevitable that, as was the case with the 2014 conference, a welldefined concern for abandoned industrial spaces would also develop in parallel, and ways would be considered for their possible management and inclusion in a setting that was no longer the one they had originally known. In short, and focusing on the main 
issue, from very early on its conferences were also sensitive to reusing tourist heritage (2001), and to its tourist uses (2001 and 2002); as well as to the bringing these to life in industrial routes and itineraries (2003) and even to its use in teaching (2004). The openness to collaborations of all kinds, borrowing from ambitious and original methodologies, and exchanging theoretical and management experiences in heritage, was of particularly note, as when they related industry's heritage to the area of cultural representations. This is demonstrated by the attention given to the intercultural dialogue that was opened for this purpose (2011) and to its relationship with collective memory or cultural landscapes (2012).

Also led by INCUNA, important publishing work has been done, being responsible for a list of works on industrial, material and intangible heritage - the value of which is more than evident. This work has been boosted by the Centre for Cultural Initiatives (CICEES) publishing house, whose work goes beyond this specific field to extend to other areas of social sciences, in addition to organising exhibitions, courses, seminars and making documentary productions. In any case, its essential work has, above all, been the publication of works inspired by INCUNA in addition to the magazine Abaco (launched in 1986), and so far has published over a hundred titles with contents that, without in any way being limited to the study of industrial patrimony, nevertheless reserve significant space in their pages for this topic.

The contents of the magazine are not, in fact, those of a publication that is strictly focused in this direction. Launched during the middle of Felipe Gonzalez's socialist government of 1982-86, and immediately following the transition period from Franco's dictatorship to democracy, its contributions were in the format of a typical political and cultural news magazine. Of the thousand or so articles, almost $50 \%$ were devoted to international policy, major social debates and current affairs. More specifically, themed issues focused on matters as varied as migration and exile ( $\left.n^{\circ} 87-88\right)$, mathematics $\left(\mathrm{n}^{\circ} 25-26\right)$, the role of trade in economic and territorial planning ( $\left.\mathrm{n}^{\circ} 73\right)$ and the history of science $\left(n^{\circ} 42\right)$. Their content also paid attention to matters such as identities, gender (with special issues such as $n^{\circ} 95-96$, devoted to feminism and the visibility of women), and history - with a special issue on an assessment of the Russian Revolution 100 years on (n ${ }^{\circ}$ 1-92). Literature and literary creation, in short, in addition to the essay on current issues, ran constantly through its contents pointing in some way to the magazine's general tone.

However, leaving this aside, topics that in one way or another could converge with the concerns of archaeology and industrial heritage made up a significant part of its subject matter. After discounting the part devoted to pedagogical and health matters, agricultural, food or ecological problems (approximately $12 \%$ ), 14\% of its contents were still given over to topics related to the organisation of work, leisure planning and the tourism or cultural industries. However, the area that was of most interest for our purposes was that which was oriented to the study of urban planning and infrastructures, industrial and technological planning, and of course, direct and themed issues focusing on tangible or intangible industrial heritage. Together, these impacted $23 \%$ of its articles. These calculations, which are in any case approximate, should not lead us to lose sight of the qualitative impression that any regular readers would gain if they encountered a publication that, although bearing the unmistakable tone of a cultural magazine, gave a highly prominent role to advocating and raising the visibility of heritage. 

the world of work, as well as to the relevance of some of its special issues, which also highlighted their themes on colourful covers, helping to make industrial heritage visible and relevant and, in a way, giving the magazine a special tone. Furthermore, it is undeniable that some of the publication's special issues stood out because they addressed arguments that were quite new at the time, or had only been treated fleetingly or superficially up until then. The first issue of the journal, under its new era which started in 1992, opened with no less than a special issue explicitly devoted to Industrial Archaeology. This was followed - some time later and in a sequence that, despite its irregularity, constituted a significant and continuous presence - by special issues devoted to cities, ports and port towns ( $\mathrm{n}^{\circ} 60-61$ and 80-81), industrial heritage and museums and their contribution to local development ( $\left.n^{\circ} 8\right)$, the collective memory of industrial heritage and its vestiges $\left(n^{\circ} 19\right)$ and the traces of industry and industrial heritage in the landscape ( ${ }^{\circ} 34$ and 80 ).

However, publishing this magazine was not the Publisher's only task, as was anticipated. As with Ábaco, its orientation did not in any way give up on cultural themes and, in a way, this gave the publishing group something unique. Approximately thirty of its publications' titles were about subjects such as history, literary creation (14 titles within the collection «La máquina de las palabras» (The Machine of Words) and catalogues and folders on artistic subjects - although in the " Tourist Guides » section, the prevalence given to industrial heritage was once again discovered with a title as significant as Patrimonio industrial de Asturias: 33 propuestas e industria, cultura y naturaleza (Asturias' Industrial Heritage: 33 Proposals for Industry, Culture and Nature). However, what was truly significant about the journal, despite its cultural presence, was that the proposals directly related to cataloguing and demonstrating the value of industrial and technological memories and vestiges undoubtedly constituted the bulk of its catalogue - thus discovering, in passing, the true vocation of the promoters behind the publishing initiative.

Thus, the "Cities and Territories» collection devoted a couple of titles to urban and industrial heritage groups such as the one on Bahía de la Habana (Bay of Havana); with interesting treatments about the changes in their old urban functions, which were reconsidered as a result of the reorganising of the Havana port near to the old fortifications and historical centre, and which led to the reclaiming of its cultural and material industrial heritage. The Iberian American region was also covered in another volume of this collection, which included Testimonios de la memoria del trabajo y la producción (Testimonies on Memories of Work and Production) in areas such as Argentina, Chile, Cuba, Mexico, Brazil, Colombia, Bolivia and Venezuela; which in 2008 issued a record of the interest aroused in these places from preserving industrial remains.Another of the publisher's collections - Catálogos fotográficos (Photographic Catalogues) - focused on the iconographic documentation collected through several of the photographic competitions that were held in parallel with the INCUNA Conferences, and which in this case focused on the traces of heritage within cultural and industrial landscapes, the related intangible heritage, the vestiges of the film production and distribution industry and the testimonies from architecture as well as the different iron and steel endowments and premises.

The two main collections by the publisher, with almost forty titles to their credit, and entitled La herencia recuperada (Recovered Heritage) and Los ojos de la memoria (The Eyes 
of Memory), again reproduced testimonies directly related to the objects of interest to INCUNA. In the case of the Recovered Heritage collection, industrial archaeology was the direct subject of one of its titles: Arqueología industrial. El pasado por venir (Industrial Archaeology. The Past to Come) - a work in which an extensive exhibition of methods and procedures for recovering and revaluing heritage was tried out, as well as its reuse through cultural tourism and in museum settings.

The collection also included a wide range of themed issues on manufacturing facilities that did not leave out Iberian America (such as the one dedicated to the Mexican preindustrial mill in Aguascalientes, or the Talapiedra thermoelectric plant in Havana) and Spain as a whole (with a study of Spain's tobacco factories) but which focused above all on Asturias industrial facilities, with a well-profiled prominence given to the mining industry (with studies of the wells at Sotón, San Luis, Minas de Llanera and Arnao), the industrial and manufacturing sector (the Trubia Arms Factory, the regional printing plants, and the industrial architecture of the Nalón Valley), the hydroelectric industry (the Grandas de Salime and Soto de Rivera plants), and even the workshops of Universidad Laboral as a territory for work-related training for industry. The collection did not leave out branches such as the food industry (with special issues on wine in Castile-La Mancha, and the sugar industry in the Mediterranean and Iberian American regions), the cultural, industrial and architectural activity of the migrants (those who returned from America to the western Cantabrian region, and the Spanish emigrants to Mexico, within special issues).

31 It even recorded memories from one of the region's particularly significant industries, through the memories of train driver José Manuel Arbesú.As for the Los ojos de la memoria (The Eyes of Memory) collection, its connection with history and commitment to preserving scientific and technological heritage, among its 20 titles are many of the communications and summaries from those who took part in INCUNA's nineteen conferences, many of which have already been commented on, in addition to a couple more special editions - one, on heritage and landscape groups associated with the production of electricity; and the other, on the architectural heritage of cinemas.

The work of the association, in terms of both publishing and raising awareness among the public and political bodies, has been somewhat unusual in recent years, in terms of the volume and entity of the work carried out, as well as because it is a strictly private organisation that takes on the work. This is by no means an ordinary situation especially considering the good reputation and packaging of its activities.

\section{University research on industrial heritage}

The research on all these subjects has, not been limited in recent years to INCUNA's only stronghold. The extension of the work of the already mentioned geographical journal Ería shows the good health that academic activity can gain from institutional platforms. However, being surely the most outstanding, solid and continuous case, it is not the only example of the links between the university and scientific-technical heritage. On this, there is a History of Science department within the University of Oviedo, which is part of the Medicine Department. Its head, Victor Alvarez Antuña, is the author of a number of works related to the history of regional scientific institutions - in particular with the University of Oviedo, and especially with the development of medicine in Asturias. On this particular subject, however, other works are available; 
those of Justo García Sánchez, for example, who is based in the University's Roman Law Department and has worked not only on surgery or on teaching medicine at this institution, but is also the author of many other works on its institutional development and teaching staff.

Botany in the region, in turn, also has studies such as those by Tomás Emilio Díaz González and Juan Luís Martínez Álvarez. The latter has, for some time, also studied the teaching of biological sciences at the University of Oviedo, the vicissitudes of the Darwinian controversy and the university's office of Natural History. There are also studies on Geology in the same university institution (by Jorge Ordaz and Jaime Truyols 2004) as well as a history of the Faculty of Sciences (by Siro Arribas 1991). In any case, and as can be seen, these are works that do not always fit with the desire to take as their basis the cataloguing and inventory of physical or immaterial scientifictechnological vestiges, to be interpreted from the socio-cultural perspective, or to use them to undertake an analysis with a similar orientation based on a history of representations.

Science and technology is, in any case, the subject of direct theoretical reflection in another of the university departments - that of Philosophy. In this case, the contributions come from one of its most prestigious research teams - the Social Studies of Science STS - headed since the beginning of 2000 by Professor José Antonio López Cerezo. The research group has managed to bring in more than two dozen researchers from the field of philosophy as well as from the fields of economics, biochemistry, pharmacy and engineering, and psychologists and sociologists, which entails taking a multidisciplinary approach to their projects and main lines of research.

Among their activities, as officially stated under their Objectives, and which Spanish and Portuguese lecturers essentially work on (although with the circumstantial collaboration of researchers from many other countries, especially Iberian American ones), they have been carrying out leading research into the meanings and social understanding of science; discussion and participation in science policies, or plans for socialisation and science education. The work of the team is, in any case, impressive in this area. Guided by STS (Science, Technology, and Society) methodological assumptions, the work of the Research Group has seen its results published in international journals and making a strong academic impact. They have also been welcomed by editorial groups such as Springer and Cambridge University Press, which are well known for their work in the scientific-technical field. Linked, on the other hand, to the publication of the STS's Revista Iberoamericana (Latin American Review), its work has also extended to promoting a specific collection within Madrid publishing house La Catarata, entitled Ensayos Ciencia y Sociedad (Essays on Science and Society).

The collection was created as a result of one of its research projects - entitled Políticas de la cultura científica (Scientific Culture Policies) and financed by the Spanish Department of the Economy and Competitiveness. However, the editorial commitment is also supported by the OEI (Organisation of Iberian American States for Education, Science and Culture) Scientific Cooperation Department. The objectives of the collection, in principle to " combine the advancement of knowledge with a high degree of dissemination in the field of social studies of science, technology and innovation ", and in the context of a dissemination purpose that is capable of combining quality scientific production with wide dissemination within society, can be said to have met their expectations. In its short history and with 16 titles to its credit, the publishing 
house is covering scientific matters that have a broad social echo, as in the cases of discussion of the risks of industrial society (El riesgo tecnológico - Technological Risk which had two volumes in 2017), the anti-vaccine movement (with a study by Emilia $\mathrm{H}$. Lopera in 2016), food safety (addressed in 2015 by Ana-Maria López-Santacruz and Montaña Cámara) and water management (a topic of Carlos Osorio Marulanda in 2015). The person within this whole research group who has made the most evident public impact is perhaps López Cerezo - one of the indisputable leaders in STS studies in Spain or within the Iberian American region, and author, editor, or co-editor of books that have wide repercussions in this field such as, to cite just a few: Ciencia, tecnología $y$ sociedad: una introducción al estudio social de la ciencia y la tecnología, 1996 (Science, Technology and Society: an Introduction to the Social Study of Science and Technology); Ciencia, tecnología y sociedad: lecturas seleccionadas, 1997 (Science, Technology and Society: Selected Readings); Ciencia y política del riesgo, 2000 (Science and risk policy), Ciencia, tecnología, sociedad y cultura en el cambio de siglo, 2001 (Science, Technology, Society and Culture at the Turn of the Century).

However, although these are indispensable aspects for reconstructing the historical track record of scientific-technical institutions in Asturias, as well as for the very important discussions about their methodological, theoretical and social implications, the truth is that the direct relationship with the material vestiges of industrial, manufacturing or technological activity tends to be indirect in all these cases, and strongly intermediated by the theoretical debate. An investigation of the institutions or techno-scientific methodology cannot, in our case, substitute the interpretative and direct work on the physical evidence of industrial activity. This latter connection, however, appears much more clearly in other areas of university research.

The Oviedo Department of Art History, which focuses on aspects of manifestations of greater aesthetic value related to the plastic arts or architecture, has over time maintained a line of focus on industrial heritage with not inconsiderable results. The pioneering manifestation of this research dimension has taken place in this university area, in an outstanding manner, through the research work of Professor Covadonga Álvarez Quintana. Since the 1980s, her work has succeeded in articulating, among other things, a morphological typology as well as a solvent socio-cultural explanation of architectural typologies such as pavilion buildings, with regional manifestations in quarters and seminars, as well as in systems of working accommodation in industrial spaces and facilities. Some pioneering companies during the industrialisation of the region - such as the Belgian Solvay \& Cie and the National Arms Factory in Trubia - also had their first and accurate cataloguing, or their studies and typological interpretations as part of her work.

Her work also extended to considerations of a more general nature, such as characterising 19th century industrial architecture, reclaiming the value of Asturias' industrial architectural heritage, and the merit and typological originality of factory installations. She even progressed the interpretation of houses as feminine places of domestic work - something that was quite new almost two decades ago But above all, perhaps the most interesting aspect of her work has been her ability to articulate, his successive collaborations on books and articles, a chronological sequence of the working class housing in Asturias from the 18th-century origins of industrialisation until well into the 20th century. 
41 At the same time, and in the same department, other interesting research has been carried out on heritage. For some years now, Natalia Tielve, for example, has been systematically working on industrial architecture. Her research links material vestiges with industrial paternalism, with its location and manifestations in coastal areas, or in manifestations in the care facilities of care homes and hospices in the contemporary period. On several occasions, she has also revisited the architecture of flagship premises such as the Royal Arms Factory in Trubia (Echaluice 2015) and has also explored the industrial buildings of the glass and crystal industry. Her work has also studied more general approaches such as when she examined the mechanistic matrices of Spanish industrial architecture as a whole, or when she highlighted the processes to recover the historic centres of Spanish cities, or the successive steps of prison architecture. Furthermore, in all this work, her involvement has been clear with the field of industrial archaeology.

This point is also seen in her work on Asturian industrial heritage and its advocacy; the proposals she made conserving and revitalising it; its uses for tourism and the problems of managing it on the part of public or private institutions. In short, what may have been her main work, the object of a book and several articles, well exemplifies her commitment to advocating the aesthetic values that can concur in architecture and industrial premises. And nothing else highlights her study of the Grandas de Salime and Soto de Ribera hydroelectric plants, where the trace of the aesthetic work of authors such as Alvarez Castelao, Fernández Casado, or Vaquero Palacios can be found. In particular, the latter would be responsible for artistic interventions of enormous impact in the Asturian power stations of Salime, Miranda, Proaza, Aboño and Tanes. This makes him one of the best exponents of the Modern Movement in Spanish industrial architecture.

María del Mar Díaz González collaborated on some of the works by the previous author. Part of her research is focused on architectural and industrial heritage, where some samples of the good work have been left. This is the case with the two research projects that, for example, she has conducted for Universidad Laboral de Gijón; certainly the most important example of architecture programmatically designed by Franco across the whole of Spain, and whose complexity - in terms of concept, dimensions and architectural ambition - make it a true model of a fascist city with all its implications of self-sufficiency, complex and integrated planning of diverse services and, above all, a paternalistic and utopian educational project in terms of its totalitarian pretensions. For the moment, the work of María del Mar Díaz provides information on her recovered documentary heritage and the evidence of her material samples, on aspects such as her general approach and her essential projects and theoretical bases, as well as progressing with an inventory of her equipment, and specifically furniture.

As is obvious, there is still a lot of ground to be studied in this massive project, although other special editions have already progressed the description and interpretation of its workshops - for example (in a collective work promoted by INCUNA), and work is already underway to study the equipment of the Farm that was annexed to it; the latter work being carried out by the team made up of the University of Oviedo's Construction and Engineering Department. The author has also focused on the list of historical companies in Asturias; in fact, her works reconstruct the types of business schools, and provide an account of the documentary heritage of the former Oviedo Arms Factory. In any event, apart from the work of Natalia Tielve, this company 
already has the studies done by María del Mar Díaz on the factory's business settlements, as well as its general urban planning approach. The essential contributions of this professor, however, are perhaps first and foremost found in the study of the graphic arts and lithographic industry in Asturias. Some of its results - such as those relating to the regional comic strip or comic strip formula, especially in the daily press - have been the subject of studies.

However, there is also no lack of research paying greater attention to the technical infrastructure of the lithographic industry, and to the cataloguing of lithographic matrices; as well as to the production of lithographic material for the fish canning industry, the pork industry or its presence in general within the advertising sphere. The interest in this peculiar heritage of the industry has also led the author to make direct proposals for the reuse and exploitation of what remains of the documentation and lithographs. Good proof of this specialist commitment is the materialisation of its concerns in monographs published with the support of publishing groups such as INCUNA, the University of Oviedo itself, and private Asturian publishers such as Trea (with a considerable academic impact in Spain, and with a very interesting collection of museum and culture related heritage, with almost 160 titles and which reserves considerable space for industrial and documentary heritage). Of the books published so far by the author alone, two of them focus explicitly on the commercial and workrelated history of lithographic establishments and the production of lithographic images from local commercial and industrial activity. Another of her books deals with the cataloguing and interpretation of lithographic matrices. In short, her patient and clarifying study of socio-cultural keys from the formal and aesthetic compositions of the actions and obligations of the mining companies found in the archive of the company HUNOSA (although also of other private and company collections) is an example of how much a well-conducted study of the cultural history of business and industrial iconology can yield.

Professor Ana María Fernández - a researcher in the same department - has meanwhile been responsible for increasingly strong specialisation in domestic interior premises, producing rather interesting aspects in terms of applied and industrial arts provision in this field. Between 2008 and 2013 she managed research teams working on official projects, commissioned by the Principality of Asturias government and the Spanish Ministry of Science, Innovation and Universities. These included topics such as interior decoration in Oviedo, between 1850 and the start of the Civil War in 1936, an exploration of the market for furniture and decorative objects in Spain since the phase of the Confiscations phase at the end of Franco's regime. Structured plans like these produced publications of significant value in a context in which the lack of papers on interior equipment, furniture, decorative objects and applied arts in the domestic sphere has been an enormously striking fact of the Spanish context.

This is where her work on the decorative systems of unique private buildings fits in such as the Asturian palace of the Selgas, a large bourgeois residence and one of the most outstanding cases of 19th century art collection. But perhaps what is of most interest to us is a collection of works that allow the firms and commercial houses to be identified in the process of interior design and conditioning in the late 19th century and even well into the 20th century. Some, like Casa Viena in Oviedo, have been the subject of individual study (Antuña 2012) 

collections of landmark Spanish public buildings, such as the Bank of Spain in Madrid. Although the topic has also been approached from more general perspectives, by immersing herself in the Spanish public spaces as a whole, or approaching the issue from a more systematic perspective, as in her book Viejos y nuevos espacios para la decoración de interiores en España, 2013 (old and new spaces for interior decoration in Spain), in which she includes works by different authors who reconstruct a journey in which public and community buildings such as libraries, town halls and places of religious worship are analysed; spaces for socialising such as casinos and places of entertainment; as well as buildings of private organisations such as banks and industrial spaces.

in any case, enables tracing of reliable hypotheses about the structural or functional kinship of these places with the domestic interiors, with which they share a notion of comfort that has been progressively refined since the 19th century - although also to demonstrate the corporate or political ambition, shown by companies and public authorities for visualising their appearance, power or prestige. The author has also focused her attention on the manifestations of this same theme in Latin American contexts such as Buenos Aires, progressing understanding of the relations in this field between Latin America and Asturias, through the architectural and decorative programme of the constructions of the indianos (Spanish Americans) who were made their wealth in America and then returned to the region, where they left a mark that is still appreciable today in the construction of their colourful country houses and small urban hotels. In addition to the above, the author has since 2012 been immersed in the tasks of organising, evaluating and designing the contents of a magazine that is unique in the Spanish context, devoted to the analysis of interiors, furniture, decoration and the applied and industrial arts in this area.

In its first issue, Res Mobilis magazine in fact claimed its desire to contribute « to filling a gap in publications dedicated to furniture and decorative objects that, whilst having excellent and established vehicles for dissemination in other geographical areas, are practically non-existent in Spain and Iberian America ». The task is being approached with an open methodology that brings together different disciplinary perspectives such as social history, art, anthropology and sociological perspectives - as part of an eminently disciplinary proposition. And it is succeeding in doing so: the magazine has been published since 2012 and in its short history, nine issues where very significant progress has been made in these areas. Furthermore, among the hundred or so articles already published, and even allowing space for the ancient and modern periods (especially the latter), the bulk - almost three-quarters - of the contributions focus on the contemporary period.

51 It is therefore, and above all, a journal oriented towards the contemporary history of furniture and interior design or urban social spaces, built with rigour, innovation and theoretical ambition - as demonstrated by the occasional articles dedicated to examining the criteria for structuring museums and exhibitions, or those focusing on theoretical or methodological issues. Among them, there are of course some outstanding collaborations that open up areas in parts of Spain that have barely been covered until now - such as car furniture and fittings, or the history of household appliances like the refrigerator, ocean liner furniture, pieces such as radiator covers, wash basins and modern desk tables, and the 19th century production of chest of 
drawers. It also deals with more foreseeable aspects that so far have not been much explored, such as street and garden lighting and furniture, the decoration of commercial buildings and businesses like pharmacies, offices and hotels, and also includes details about the owners, manufacturers or commercial furniture houses. Lastly, details are also added about the participation of women in the profession of architecture or the design of furniture... In conclusion, a whole world of, at times, minimal productions, whilst others are charged with strong significance in the physiognomy and appearance of cities but in any cases essential in daily urban and industrial life, and about which little was known until now.

\section{The late incorporation of contemporaneism}

The last to arrive in this progressive march of incorporating the material vestiges of industry and contemporary economic and social activity have generally probably been, and in an apparently unexpected way, the contemporaneist historians. The strong commitment to social history of this area of researchers in Asturias undoubtedly contributed to this late inclusion of the industry's heritage issues among their concerns. But apart from this specialisation and leaving aside the care required by a sector like this - which is indispensable in regional history - it was also clear that other factors were at play. The withdrawal of social history for these years in relation to these issues was also related to a social history that, following the "historiographic revolution » of the 1960s, and despite the options for frank renewal that opened up from the 1980s, would still give a leading role to the sphere of production and, especially, to that of production relations as structural determinants of historical evolution. The material vestiges of economic and social activity, in this regard, at the same time as the cultural dynamic itself was thus placed in a subordinate position, and to a certain extent predetermined in terms of historical narrative.

This left a minimal role for interpreting and studying industrial archaeology or the immaterial testimonies of the industrial past. At the same time, the drift of an industrial archaeology that showed few points of contact with social and cultural history cannot be excluded either. As it was developed in the 1980s, and in spite of everything and in part also in the 1990s, the studies on the industrial heritage were seen from the most canonical social history as a strongly descriptive commitment, excessively dependant on some markedly taxonomic levels in their technologicalscientific description, and little open to its insertion into the play of tensions and social dynamics, or the interpretation from the ideological or political standpoint. Whether one wanted it or not, everyday reality established a separate and strongly autonomous evolution of both social history and historical archaeology - each confined to its own field of specialisation, and with limited stimulus towards methodological or theoretical exchange in regard to the bases of their respective programmes of research.

Since the beginning of 2000, however, there have been some signs of curiosity which, in a way, have marked a suggestive turn not only for social historians, but for all studies on industrial heritage itself. The interest of these investigations was, without a doubt, on the markedly social orientation under which they were registered, in their desire to insert them into a socio-cultural methodology and in an openness, at all times within these coordinates, to the interweaving of disciplines and methods within an eminently interdisciplinary framework. Perhaps the formation in 2000 of a team of 
contemporaneist researchers from the History Department and based on the explicit demand of the state company HUNOSA (Hulleras del Norte SA), was the first of these signs of change. The project was structured around the cataloguing of the company's documentary collections over six years, between 2000 and 2005, and affected one of the most important company archive collections in Asturias, together with that of ENSIDESA - the large state-run steel company and other major point of reference in the region's economic history after the 1960s.

The historical collections, which brought together documentation about the old mining companies prior to nationalisation and consolidation carried out by this organisation since 1967 certainly had an enviable wealth, with documents that would go back to the end or even the middle of the 19th century. The aim was to deal with the problems arising from the accelerated closure of coal pits, and the massive influx of documentation from the former companies to the Central Archives offices. In 2003, the Pozu Fondón Archive housed some 5,800 boxes of documentation, over 1,000 archive books and almost 7,000 plans, in addition to bibliographic and specialist periodical collections, along with a further 236.12 cubic metres of documentation that were still waiting to be processed and classified. In order to deal with this situation and to undertake the final stages of cataloguing the company's historical collection (that is, the documentation prior to its creation in the 1960s), the company's own staff was to be joined by a university team made up of some fourteen people, including geographers, historians, philologists, archivists and administrative staff.

Some of these were native to the mining areas themselves and had direct knowledge of both toponymy and vocabulary as well as local variations of the usual terminology used in the sector. As interesting as the work carried out in terms of document cataloguing was the fact that, in conjunction with the company, a series of monographs would be published, based on direct consultation of its collections, and with the direct participation of some of the members of the university team in charge of the project. A series of monographs would be published by HUNOSA's Organisation and Training Department in the form of a company gift, coinciding with the organisation of annual exhibitions on the work of companies at the Asturian Trade Fair. After the project was concluded, an initial description of the Archive could be obtained and presented in the corresponding special issue (in 2008) and in which, apart from classification of the spatial and constructive framework of the physical headquarters of the Pozo Fondón and its installations (the Archive headquarters), a description of the main company collections contained within it was accessed via six successive chapters - specifically, those of Hullera Española, Hulleras de Turón, Hulleras de Veguín y Olloniego, Minas de Langreo y Siero, Duro-Felguera, and Lieres-Solvay.

Others had been added in previous years to this volume, which closed the project's cycle of activity. At the request of the research team, for example, a geographical monograph had been carried out on one of the least studied vestiges of mining activity - specifically, the slag heaps, examined here through the sample of La escombrera de Reicastro (The Reicastro Slag Heap) (by Manuel Maurín, in 2005). Three different studies were carried out with the archive funds: the first on La vivienda de empresa en la planoteca del Archivo Histórico de Hunosa (The Company House in the Hunosa Historical Archive Map Room), by Jorge Muñiz (2003); another on Las lámparas de mina en el Archivo Histórico de Hunosa (Mining Lamps in the Hunosa Historical Archive), by Mercedes Mateos and Jorge Muñiz (2004)); and another the following year on materials and 
security systems documented in the Archive, by Carlos García. Last, starting with the collection of actions and obligations contained in the Archive, but quickly exceeding it and gathering other samples from private collections or institutions, such as the former Bank of Asturias (later migrated to the Catalan Bank of Sabadell archives) including the collection of Viña Lithographs and the Miguel Areces collection, among others - a study was undertaken, which has already been referred to, and which went beyond the simple iconographic description of decorative or lithographic themes and systems, to quickly take on a social and cultural orientation. This was the analysis of The Actions and Obligations of the Hunosa Archive. Composiciones Formales y Estética del Trabajo (Formal Compositions and Aesthetics of Work) (1833-1973), by María del Mar Díaz, attached to the University of Oviedo's Art History Department.

In one way or another, some of the employees in that pioneering team ended up joining other university groups of historians, geographers and documentalists. Jorge Muñiz, who is currently contractually part of the University of Oviedo's core group of contemporaneists, is an example of these. His doctoral thesis, initially written in connection with the above-mentioned project, would be quite a novelty some time later - both from the point of view of social history and in terms of the proposal he made of re-reading industry and industrial workspaces. Published under the title Del pozo a casa. Genealogías del paternalismo minero contemporáneo en Asturias (From Pit to House. Genealogies of Contemporary Mining Paternalism in Asturias), by examining three companies (Solvay y Cía., Real Compañía Asturiana de Minas and Hullera Española) he put forward an analysis of corporate paternalistic policies in the light of their attempts to interfere in the mechanisms of sociability and leisure of popular sectors.

Furthermore, using a methodology influenced by Foucault's panoptistas proposals, his research reinterpreted the usual urban, industrial and domestic spaces that integrated the everyday environment of the working and popular classes, linking them to actual space management projects linked to the disciplinary techniques of the business world. Although from the beginning his work has combined all these matters with his wellprofiled concern for the most classical social and cultural history, his analyses have never lacked the organisation of space, the derivations of the processes of urbanisation, or the organisation of factory territories - as when he examines the history of the railway as the articulator of social space, or the functions of orchards in the model of staff housing assumed by paternalism. In the same line of research on industrialisation, there has also been a study of technology transfers between Belgium and Asturias in the mid-19th century, the migration processes of qualified workers between areas such as Asturias and Belgium or France, the interconnection of trade union models between the basins of northern France, Belgium and Asturias, as well as the influence that the similarity of geological or technological conditions that can be established between the mining basins of these three areas has had on all these exchanges.

Although cases such as these are obvious examples of direct reflection on the physical vestiges of economic activity of the last two centuries from the more canonical field of contemporary history, the links between the cultural and heritage of industrialisation and historical research in this era are too evident not to have led to other research results. Rubén Vega, for example, who has long been involved in the history of social movements, and especially Francoism and the Transition, has lately moved closer to records that are closer to the subject matter of interest here. It has done so directly, for example, when he organised the Asturias Historical and Industrial Heritage 
Conferences, holding three editions between 2016 and 2018 and when he carried out studies on the consequences of industrial reconversion, and especially on shipyards. The results from this, among others, are studies such as the monograph dedicated to Astilleros en el arco atlántico (Shipyards in Atlantic Europe), 2013.

The author's approach essentially focuses on the records of workers' memories and industrial activities; the last of the above-mentioned Historical and Industrial Heritage Conferences dealt with the theme of Lugares de la Memoria (Places of Memory), highlighting the traces left in the collective memory of the activity of certain mining pits, or in the scenarios of the Asturian Insurrection of October 1934. Similar considerations could be made regarding his reflections on the representations of the industrial past in Asturias. The author has recently also set up a research team to study "Socio-cultural change, memory, heritage and identities in contexts of deindustrialisation ", which has launched an official project with funding from Spain's Ministry of Economy, Industry and Competitiveness that will run until 2020, and which has already shown signs of activity by organising seminars such as the one held in November 2018 on Escena y Pantalla. Representaciones culturales del pasado industrial (Scene and Screen. Cultural representations of the industrial past).

The work on recovering intangible heritage is, in any case, also a sign of identity among another of the members of the team of contemporary artists of the University of Oviedo - and specifically in the case of Luis Benito García Álvarez. This researcher is the author of a doctoral thesis that has already been published, Sidra y manzana en Asturias. sociabilidad, producción y consumo (1875-1936) (Cider and Apple in Asturias. Sociability, Production and Consumption), 2013. It not only examines issues related to the anthropological dimensions of the forms of commensality, and the dietary characteristics of this drink (highly important in the structure of consumption in the region), but also makes progress in classifying the historical patterns of its productive development, as well as in characterising its network of production centres: a network which is not alien to large installations, with technological equipment and advanced production solutions, but which above all rests on a network of small producers, often with a craftsman structure, but who dot the whole area with their premises. The importance of this fragmented network of small infrastructures, but above all the derivations of cultural forms and consumption patterns of marked originality, have led to their work, chained as part of a number of collaboration projects with the Principality's government, for cataloguing aspects of cider culture, as well as for their official protection as an Asset of Cultural Interest. He is currently also working intensely on preparing the cider culture candidacy for it to be officially classed by UNESCO as Intangible Heritage.

63 As can be seen, both in terms of the reading of spaces as a semiotic key, and in terms of the cultural interpretation of documentary heritages of industry such as that deposited in the HUNOSA Archive; or in terms of the exploration of the intangible heritage of reports from past economic and working activity, the dominant direction in this whole range of works is clearly socio-cultural historiographic. The author of this work has tried to do nothing else, insofar as he has approached the field of the study of material and immaterial vestiges of the industrial past. This was tested using the basic materials contained within the HUNOSA Archive's documentation. He worked on its Evaluación y criterios de ordenación y recuperación del Patrimonio Histórico Documental de Hunosa (Evaluation and Criteria for Managing and Recovering Hunosa's Historical 
Documentary Heritage) project, as has been confirmed, several years since his appointment.

Finally, on a much more theoretical level and attached to methodological assumptions, these are the parameters that are aimed to be based on the recent contribution, made before INCUNA in 2017 and recently published in Arqueologías de la vida cotidiana. Una propuesta metodológica (Archaeologies of Daily Life. A Methodological Proposal), where we review the implications of the notion of the everyday and apparently banal, in the working environment and in leisure time (a preferential space of contemporary society's modern cultural industries) when reading our most usual environment - that which explains and refers to the ordinary life of people in the social environment that to us is more frequent.

\section{BIBLIOGRAPHY}

ÁLVAREZ ANTUÑA Víctor, «Fulgor y muerte de los estudios médicos ovetenses en las postrimerías del siglo XVIII. Los orígenes de la enseñanza de la Medicina en Asturias (Fulgor and the Death of Oviedo's Medical Studies at the End of the 18th Century. The Origins of the Teaching of Medicine in Asturias) ", Tradición de futuro (Tradition of the future). Exposición Cuatro Siglos de Historia de la Universidad (Exhibition Four Centuries of University History), Oviedo, University, 2008

ÁLVAREZ QUINTANA Covadonga, « La tipología del edificio de pabellones. Una realidad escasamente conocida de la arquitectura del siglo XIX (The typology of the pavilion building. A little known reality of 19th century architecture) », Studium: Revista de humanidades (Studium: Humanities Magazine) 10, 2004

- «Solvay \& cie: historia y arquitectura de una empresa belga en Asturias » (Solvay \& Co: history and architecture of a Belgian company in Asturias), Boletín del Real Instituto de Estudios Asturianos, (Royal Institute of Asturian Studies Bulletin) 150, 1997

- « Arquitectura industrial en la fábrica de armas de Trubia: naves y espacio de trabajo (1794-1936)» (Industrial Architecture in the Trubia Arms Factory: Buildings and Working Space), Boletín del Real Instituto de Estudios Asturianos (Royal Institute of Asturian Studies Bulletin), 141, 1993

- « Nacimiento y evolución de la casa de empresa en la fábrica nacional de armas de Trubia (1794-1936) (Birth and Development of the Company House at the National Arms Factory in Trubia) ", Liño: Revista anual de historia del arte, (Liño: Annual Art History Magazine), 10, 1991

- « Casa y carbón: la vivienda minera en la cuenca del Caudal (House and Coal: the Mining Dwelling in the Caudal Basin) », Liño: Revista anual de historia del arte (Liño: Annual Art History Magazine), 10, 1991

- «El poblado/colonia de Bustiello 1890-1925: un monumento de arqueología industrial que relaciona Asturias con Catalunya » (The Village/Colony of Bustiello 1890-1925: a Monument of Industrial Archaeology that Links Asturias to Catalonia), El Mediterráneo y el Arte Español: Actas del 
XI Congreso del CEHA, (Mediterranean and Spanish Art: Minutes from the 11th CEHA Conference), Valencia, 1998

- « Sobre el modelo puro de poblado industrial y las contaminaciones urbanas: El caso de la colonia fabril de Trubia entre 1890 y 1936 » (Regarding the Pure Model of Industrial Village and Urban Pollution: The Case of the Trubia Factory Colony Between 1890 and 1936), VIII Congreso Internacional para la Conservación del Patrimonio Industrial (8th International Conference for the Conservation of Industrial Heritage), Madrid, Ministry of Public Works, 1995

ALVARGONZÁLEZ RODRÍGUEZ Ramón María, Gijón: industrialización y crecimiento urbano (Gijón: Industrialisation and Urban Growth), Salinas, Ayalga 1977

ARRIBAS JIMENO Siro, University of Oviedo Sciences Department: Historic Study, Oviedo, University, 1984

DÍAZ GONZÁLEZ María del Mar, « Universidad Laboral de Gijón (Asturias). El primer gran proyecto filantrópico gironiano al servicio de la patria (The first great philanthropic project in Gironde in the service of the country): 1945-1978 ", Hispania Nova: Revista de historia contemporánea (Contemporary History Magazine), 15, 2017

- « El mobiliario de la Universidad Laboral de Gijón (Asturias): adjudicaciones a Biosca de 1953 a 1962 (The furniture of the Universidad Laboral de Gijón, Asturias: awards to Biosca from 1953 to 1962 », Locus amoenus, 15, 2017

- « La escuela primaria de la minería en el Concejo de Aller, Asturias. Del primer franquismo al tardo franquismo 1940-1975 » (The Primary School of Mining in Concejo de Aller From Early Francoism to Late Francoism), Vegueta: Anuario de la Facultad de Geografía e Historia (Vegueta: Geography and History Department Yearbook), 15, 2015

- « De la litografía industrial a la creación artística: uso y gestión del Patrimonio Histórico Litográfico Asturiano » (From Industrial Lithography to Artistic Creation: Use and Management of the Asturian Lithographic Heritage), RIIPAC: Revista sobre Patrimonio Cultural (Magazine on Cultural Heritage), 4, 2014

- « Los litografiaos de les conserveres de pescáu y cárnicos, propaganda y enfotu visual » (The Lithographs of the Fish and Meat Canners, Propaganda and Visual Emphasis), Asturias: Memoria encesa d'un país, 15, 2003

- « El patrimonio litográfico asturiano y el proceso de catalogación de los depósitos de matrices litográficas y metalográficas » (Asturian Lithographic Heritage and the Process of Cataloguing Lithographic and metalloGraphic Matrix deposits), Merida. Ciudad y patrimonio: Revista de arqueología, arte y urbanismo (City and heritage: Journal of Archaeology, Art and Urbanism), 6, 2002

- « La colonia de San Feliz un poblado de empresa vinculado a la fábrica de Armas de Oviedo (1921)» (The Colony of San Feliz, a Company Town Linked to the Oviedo Arms Factory), Boletín del Real Instituto de Estudios Asturianos (Royal Institute of Asturian Studies Official Gazette). 151, 1998

- « El individuo y la sociedad de consumo desde los cromolitografiados publicitarios asturianos (1920-1960)» (The Individual and Consumer Society from the Asturian Advertising Chromolithographs (1920-1960), Mirando a Clío: el arte español espejo de su historia: actas del XVIII Congreso del CEHA (Looking at Clío: Spanish Art as a Mirror of its History: Proceedings from the 18th CEHA Conference), Santiago de Compostela, 2012

- «Las chacinerías asturianas desde los cromolitografiados publicitarios » (Asturian Butcher's Shops from Advertising Chromolithography), Patrimonio industrial agroalimentario: Testimonios 
cotidianos del diálogo intercultural (Agro-food Industrial Heritage: Daily Testimonies from Intercultural Dialogue), Gijón, INCUNA, 2009

- « Desarrollo histórico y urbanístico de un recinto vulnerable: la Fábrica de Armas de Oviedo », Del hierro al acero: forjando la historia del patrimonio industrial metallúrgico (Historical and Urban Development of a Vulnerable Site: the Oviedo Arms Factory, From Iron to Steel: Forging the History of Metallurgical Industrial Heritage), Gijón, INCUNA, 2008

- « El patrimonio documental de la Fábrica de Armas de Oviedo », Patrimonio industrial e historia militar: nuevos usos en el urbanismo y en la cultura (The Documentary Heritage of the Oviedo Arms Factory, Industrial Heritage and Military History: New Uses in Town Planning and Culture), Gijón, CICEES, 2006

- (with Orlando Campo), « La ilustración gráfica y la fotografía » (Graphic illustration and photography), Historia de la prensa en Asturias (History of the Press in Asturias). I, Oviedo, Press Association, 2004

- (with Natalia Tielve), « Arte e Industria. Un itinerario litográfico por Asturias » (Art and Industry. A Lithographic Itinerary Through Asturias), Rutas Culturales y Turísticas del Patrimonio Industrial, (Cultural and Tourist Routes Through Industrial Heritage) Gijón, CICEES, 2004

- - « Reutilización del patrimonio industrial de las artes gráficas (Reuse of the Industrial Heritage of the Graphic Arts).The Frans Masereel Centrum in Kasterlee (Belgium), paradigma de un centro internacional de estampación artística » (paradigm of an international centre for artistic printing), Patrimonio industrial: Lugares de la memoria (Industrial Heritage: Places of memory). Proyectos de reutilización en industrias culturales, turismo y museos (Reuse Projects in Cultural Industries, Tourism and Museums), Gijón, CICEES, 2002

- « El patrimonio litográfico asturiano, estado de conservación y posibilidades de explotación » (Asturian Lithographic Heritage, State of Conservation and Options for Exploitation), Arqueología industrial, patrimonio y turismo cultural (Industrial Archaeology, Heritage and Cultural Tourism), Gijón, INCUNA, 2001

- «El impreso comercial litografiado en Asturias (1937-1970)» (The commercial lithographic print in Asturias), Arte e identidades culturales: actas del XII Congreso Nacional del Comité Español de Historia del Arte (Art and Cultural Identities: Proceedings from the 12th National Conference of the Spanish History of Art Committee), Oviedo, CEHA, 1998

- Los establecimientos litográficos asturianos: historia mercantil y desarrollo laboral (Asturian Lithographic Establishments: Commercial History and Work-related Development), Gijón, CICEES, 2009

- Las acciones y obligaciones del Archivo de Hunosa: composiciones formales y estética del trabajo (1833-1973), (The Actions and Obligations of the Hunosa Archive: Formal Compositions and Work Aesthetics), Oviedo, Hunosa, 2007

- Asturias litografiada: El comercio y la industria en imágenes, 1900-1970 (Asturias Lithographed): Trade and Industry in Images), Gijón, Trea, 2004

- El impreso comercial litografiado en Asturias (1920-1973): catálogo de las matrices litográficas y metodológicas (The Commercial Lithographic Print in Asturias (1920-1973): Catalogue of Lithographic and Methodological Matrices), Oviedo, University, 2003

DÍAZ GONZÁLEZ Tomás Emilio, NAVARRO ANDRÉS Florentino, « Apuntes para la historia de la Botánica astur » (Notes for the History of Asturian Botany), Boletín del Instituto de Estudios Asturiano, Suplemento de Ciencias (Asturian Studies Institute Gazette, Science Supplement), 21, 1975 
ERICE SEBARES Francisco, « La Universidad de Oviedo bajo el franquismo » (The University of Oviedo under Franco), 1608-2008. Tradición de futuro (Tradition of the future). Exposición Cuatro Siglos de Historia de la Universidad (Exhibition Four Centuries of University History), Oviedo, University, 2008

GARCÍA ÁLVAREZ Luis Benito, Sidra y manzana en Asturias, sociabilidad, producción y consumo (1875-1936) (Cider and Apple in Asturias, Sociability, Production and Consumption), Oviedo, KRK, 2013

GARCÍA BLANCO José María, GUTIÉRREZ PALACIOS Rodolfo, « El declive de las áreas de antigua industrialización: Un análisis sociológico del caso asturiano » (The Decline of the Areas of Ancient Industrialisation. A Sociological Analysis or the Asturian Situation), Sociología del trabajo (Sociology of Work), 8, 1989-1990

GARCÍA DE CASTRO César and RÍOS GONZÁLEZ Sergio, La universidad laboral de Gijón, Gijón, Trea, 1997

GARCÍA FERNÁNDEZ Carlos, El archivo de HUNOSA y la construcción de la Seguridad en la Minería del Carbón asturiana (The HUNOSA Archive and the Construction of Safety in Asturian Coal Mining) Oviedo, HUNOSA, 2005

GARCÍA SÁNCHEZ Justo, « La Facultad de Medicina de Oviedo del siglo XVIII » (The Oviedo School of Medicine in the 18th century), Boletín del Real Instituto de Estudios Asturianos (Royal Institute of Asturian Studies Official Gazette), 52, 1998

- La medicina en la Universidad de Oviedo (siglo XVIII) (Medicine at the University of Oviedo (18th century), Oviedo, University, 1996

GONZÁLEZ GARCÍA Martha I., CRISTINA PALMA Conceiçao, El riesgo tecnológico I. Percepción y comunicación social (Technological Risk I. Perception and Social Communication), Madrid, La Catarata, 2017

- El riesgo tecnológico II. Impactos sociales (Technological Risk II. Social Impacts), Madrid, La Catarata, 2017

GUTIÉRREZ PALACIOS Rodolfo, VÁZQUEZ GARCÍA Juan Antonio, « La gestión del declive minero » (Managing the Decline of Mining), Revista de economía (Economy Magazine), 11, 1991

HUERTA NUÑO Manuel Antonio, «El patrimonio industrial, ¿un patrimonio oxidado? », Primeras Jornadas de Patrimonio Cultural de Oviedo (Industrial Heritage, a Rusty Heritage?: First Oviedo Cultural Heritage Conference), held in October 2015, Oviedo, Gijón, Trea, 2017

LOPERA PAREJA Emilia H., El movimiento antivacunas. Argumentos, causas y consecuencias (The AntiVaccine Movement. Arguments, Causes and Consequences), Madrid, La Catarata, 2017

LÓPEZ CEREZO José Antonio (with M. González and J.L. Luján), Ciencia, tecnología y sociedad: una introducción al estudio social de la ciencia y la tecnología (Science, Technology and Society: an Introduction to the Social Study of Science and Technology), Madrid, Tecnos, 1996

- (with M. González and J.L. Luján), Ciencia, tecnología y sociedad: lecturas seleccionadas (Science, Technology and Society: Selected Readings), Madrid, Ariel, 1997

- (with J.L. Luján), Filosofía de la tecnología (Philosophy of Technology), (Theorem special issue, 17, 1998

- (with J.L. Luján), Ciencia y política del riesgo (Risk Science and Policy), Madrid, Alianza, 2000

- (with J. M. Sánchez Ron), Ciencia, tecnología, sociedad y cultura en el cambio de siglo (Science, Technology, Society and Culture at the Turn of the Century), Madrid, New Library, 2001 
LÓPEZ-SANTACRUZ SERRALLER Ana Maria, CÁMARA HURTADO Montaña, Seguridad alimentaria. La comunicación de riesgos y el desarrollo tecnológico (Food Safety. Risk Communication and Technological Development), Madrid, La Catarata, 2015

MARTÍN RODRÍGUEZ Ángel R., CUARTAS SUÁREZ F., SUÁREZ DOMINGUEZ Francisco José., DEL COZ DÍAZ Juan José, LOZANO MARTÍNEZ-LUENGAS Alfonso Gerónimo, Universidad Laboral de Gijón workshops, Gijón, CICEES-INCUNA, 2006

MARTÍN RODRÍGUEZ Angel, CUARTAS SUÁREZ Antonio Eugenio, SUÁREZ DOMINGUEZ Francisco José, DEL COZ DÍAZ Juan José, LOZANO MARTÍNEZ-LUENGAS Alfonso Gerónimo, « Rehabilitación de los talleres de la Universidad Laboral de Gijón » (Upgrading the Universidad Laboral de Gijón's Workshops), ReCoPaR e-Magazine, 5, 2007

MAURÍN ÁLVAREZ Manuel, La escombrera de Reicastro (The Reicastro Slag Heap), Oviedo, HUNOSA, 2005

MUÑIZ SÁNCHEZ Jorge, La vivienda de empresa en la planoteca del Archivo Histórico de Hunosa (The Company House in the Hunosa Historical Archive Map Room), Oviedo, HUNOSA, 2003

- (with Mercedes Mateos), Las lámparas de mina en el Archivo Histórico de Hunosa (Mine Lamps in the Hunosa Historical Archive), Oviedo, HUNOSA, 2004

- Del pozo a casa. Genealogías del paternalismo minero contemporáneo en Asturias (From Pit to House. Genealogies of Contemporary Mining Paternalism in Asturias), Gijón, Trea, 2007

-« Travail, espace et conflits sociaux dans la Compagnie Royale Asturienne des Mines », in KOHLER Florent (éd.), Stéréotypes culturels et constructions identitaires, Tours, Presses Universitaires François Rabelais, 2005

- « El ferrocarril minero de la Sociedad Hullera Española en Aller (Asturias) como articulador del espacio social » (The Mining Railway of the Spanish Coal Society in Aller (Asturias), as an Articulator of Social Space), IV Congreso de Historia Ferroviaria (4th Conference of Railway History), Fundación de los Ferrocarriles Españoles (Spanish Railway Foundation), Madrid, 2006

- « El germen belga de la industrialización en el Norte de España (The Belgian Germ of Industrialisation in Northern Spain). Asturias, 1833-1838 », Signos Históricos (Historical Signs), 41, 2016

- « Los inicios de la emigración de trabajadores cualificados en la industria asturiana: la Real Compañía Asturiana de Minas a principios del siglo XX » (The Beginnings of the Emigration of Skilled Workers in Asturian Industry: the Royal Asturian Mining Company at the Beginning of the 20th Century), Historia Social (Social History), 87, 2017

- «Seguridad minera y consolidación del movimiento obrero en el Noroeste de Francia en el período de entreguerras » (Mining Security and the Consolidation of the Workers' Movement in Northwest France in the Interwar Period), Ayer, 100, 2015

- « Workers' Gardens and Industrial Paternalism in the Société des Mines de Lens (France) at the Beginning of the 20th Century ", Contemporary History, 43, 2011

- « Le réformisme dans le syndicalisme minier en Espagne au début du XX $\mathrm{XX}^{\mathrm{e}}$ siècle », Le Mouvement Social, 234, 2011

- « El germen belga de la industrialización en el Norte de España (The Belgian Germ of Industrialisation in Northern Spain). Asturias, 1833-1838 », Signos Históricos, 41, 2016

- « Los inicios de la emigración de trabajadores cualificados en la industria asturiana: la Real Compañía Asturiana de Minas a principios del siglo XX » (The Beginnings of the Emigration of 
Skilled Workers in Asturian Industry: the Royal Asturian Mining Company at the Beginning of the 20th Century), Historia Social (Social History), 87, 2017

- «Seguridad minera y consolidación del movimiento obrero en el Noroeste de Francia en el período de entreguerras » (Mining Security and the Consolidation of the Workers' Movement in Northwest France in the Interwar Period), Ayer, 100, 2015

- «Emigración y estrategias sindicales en los inicios del Sindicato de los Obreros Mineros de Asturias (SOMA)» (Migration and Union Strategies in the Early Days of the Mining Workers' Union of Asturias), Historia Social (Social History), 68, 2010

- «Sidra y antialcoholismo patronal en la mina de Lieres (Asturias) durante el siglo XX » (Cider and Employer Anti-alcoholism at the Lieres Mine (Asturias) During the 20th Century), Ayer, 73, 2009

- «Paternalismo y construcción social del espacio en el poblado de Arnao (Asturias)» (Paternalism and Social Construction of Space in the Village of Arnao (Asturias), 1855-1937, Scripta Nova. Geography and Social Sciences e-Journal, 249, 2007

- « El entorno social de Minas de Lieres: organización espacial, urbanismo y sociabilidad (The Social Environment of Minas de Lieres: Spatial Organisation, Urbanism and Sociability), Sociología del Trabajo (Sociology of Work), 52, 2004

LLORDÉN MIÑAMBRES Moisés, La producción del suelo urbano en Gijon (1860-1975) (Urban Land Production in Gijon), Oviedo, Official College of Architects of León and Asturias, 1978

MARTÍNEZ ÁLVAREZ Juan Luís, « Darwinistas y antidarwinistas asturianos » (Asturian Darwinists and Anti-Darwinists), Revista de Biología de la Universidad de Oviedo (University of Oviedo Journal of Biology), 1, 1982

- and LASTRA LÓPEZ Carlos, « Historia de la enseñanza de las Ciencias biológicas en la Universidad de Oviedo (hasta 1968) » (History of the Teaching of Biological Sciences at the University of Oviedo - until 1968), Revista de la Facultad de Ciencias de Oviedo (Oviedo's Sciences Department Journal), 17-18, 1978

- « Algunos datos sobre el antiguo Gabinete de Historia Natural de la Universidad de Oviedo » (Some details about the University of Oviedo's former Natural History Office), Boletín de la Real Sociedad Española de Historia Natural (Spanish Royal Society of Natural History Gazette), 79, 1984

MORALES MATOS Guillermo, Introducción al estudio geográfico de la siderurgia asturiana (Introduction to the Geographical Study of the Asturian Iron and Steel Industry), Oviedo, Geography Department, 1976

NADAL Jordi, El fracaso de la revolución industrial en España (The Failure of the Industrial Revolution in Spain), 1814-1913 Barcelona, Ariel, 1975

OSORIO MARULANDA Carlos, La gestión del agua. Implicaciones de la participación de expertos y ciudadanos (Water Management. IMPLICATIONS from the Participation of Experts and Citizens), Madrid, La Catarata, 2015

QUIRÓS LINARES Franscisco, « Nueva instalación de la Sección de Geografía » (New Geography Section facility), Ería, 6, 1984

SIERRA ÁLVAREZ José, El obrero soñado: ensayo sobre el paternalismo industrial (The Dreamed-of Worker: An Essay on Industrial Paternalism (Asturias, 1860-1917), Madrid, Siglo Veintiuno de España Editores (21st-century Spain Publishers), 1990 
SUÁREZ ANTUÑA Faustino, Carbón para España. La organización de los espacios hulleros asturianos (Coal for Spain. The Organisation of Asturias' Coal Spaces) Oviedo, KRK, 2006

- « El patrimonio histórico industrial minero. Características y problemática » (Historical Industrial Mining Heritage. Features and Issues), Boletín de Letras del Real Instituto de Estudios Asturianos (Royal Institute of Asturian Studies Gazette), 166, 2005

TIELVE GARCÍA Natalia, « Company Towns: architecture and paternalism of the Compagnie Royale Asturienne des Mines to Spanish Glassworks », Estoa. The University of Cuenca Architecture and Urbanism Department's Magazine, 12, 2018

- « La memoria del pasado industrial: Conservación, reutilización y creación de nuevos equipamientos (Memory from the Industrial Past: Conservation, Reuse and Creation of New Equipment) », E-rph: Revista electrónica de Patrimonio Histórico (Historical Heritage e-Magazine), 19, 2016

- « Arquitecturas del agua. Patrimonio industrial y espacio litoral asturiano (Water Architectures. Asturias' Industrial Heritage and Coastal space) », Abaco: Revista de cultura y ciencias sociales (Culture and Social Science Journal), 80-81, 2014

- « Artes industriales y vidriería (Industrial arts and glassware). La Compagnie de Saint-Gobain in Spain: From the Royal Manufactures to the Architectural Modernity of Spanish Glassware ", Ars longa: cuadernos de arte, 23, 2014

- « The international style: Imagen, programa y matriz mecanicista en la arquitectura de la industria en España » (Image, Programme and mecHanistic Matrix Within the Architecture of Industry in Spain), ERAS: European Review of Artistic Studies, 4, 2013

- « Arte, diseño y arquitectura industrial en la labor de Joaquín Vaquero Palacios (1900-1998) (Art, Design and Industrial Architecture in the Work of Joaquín Vaquero Palacios) », Norba: Art Magazine, 31, 2011

- « The A.R.I. in Extremadura, an instrument for rehabilitating historical centres », Merida. Ciudad y patrimonio: Revista de arqueología, arte y urbanismo (City and Heritage: Journal of Archaeology, Art and Urbanism), 6, 2002

- « Una aproximación a la arquitectura penitenciaria decimonónica: la cárcel de partido de Gijón » (An Approach to 19th Century Prison Architecture: the Party Prison in Gijón), Boletín del Real Instituto de Estudios Asturianos (Royal Institute of Asturian Studies Official Gazette), 150, 1997

- « Entre el arte y la técnica : las centrales de Joaquín Vaquero Palacios (1900-1998)» (Between art and technique : the Power Stations of Joaquín Vaquero Palacios), Joaquín Vaquero Palacios: la belleza de lo descomunal (Joaquín Vaquero Palacios: the Beauty of the Huge), Madrid, Función ICO, 2018

URÍA GONZÁLEZ Jorge (Coord.), Hunosa Historical Archive, Oviedo, HUNOSA, 2008

- « Arqueologías de la vida cotidiana » (Archaeologies of everyday life), Criss Crossing: patrimonio, paisajes urbanos, creación industrial y culturas contemporáneas (Criss-Crossing: Heritage, Urban Landscapes, Industrial Creation and Contemporary Cultures), Gijón, CICEES, 2018.

VEGA GARCÍA Rubén, « Looking back: Representations of the Industrial Past in Asturias », Industrial Heritage and Regional Identities, London, Routledge, 2018

- « Travailler dans la construction navale en Espagne. Pratiques et mémoires », Travail, travailleurs et ouvriers d'Europe au XXe siècle, Dijon, Éditions Universitaires de Dijon, 2016

- Shipyards in the Atlantic Europe. Work, History and Heritage, Gijón, Trea, 2013 
- Espacios portuarios y villas costeras: modelos de estrategias urbanísticas y patrimoniales de regeneración $y$ transformación del litoral asturiano (Port Spaces and Coastal Towns: Models of Urban and Heritage Strategies for the Regeneration and Transformation of Asturias' Coast), Oviedo, Eikasia, 2014

- (Coord.), La Real Fábrica de Armas de Trubia: patrimonio de la industrialización en España (The Royal Arms Factory of Trubia: a Heritage of Industrialisation in Spain), Gijón, CICEES, 2010

- « La intervención del ingeniero Carlos Fernández Casado en ENDASA: ejemplo modélico dentro de la concepción de un espacio industrial » (The Intervention of Engineer Carlos Fernández Casado in ENDASA: a Model Example Within the Conception of an Industrial Space), Del hierro al acero: forjando la historia del patrimonio industrial metalúrgico (From Iron to Steel: Forging the History of Metallurgical Industrial Heritage), Gijón, INCUNA, 2008

- « La rentabilización del patrimonio como recursos turístico. De asilo a espacio para el arte: el caso del museo Nicanor Piñole » (The Profitability of Heritage as a Tourist Resource. From Asylum to Space for Art: The Case of the Nicanor Piñole Museum), La multiculturalidad en las artes y en la arquitectura: XVI Congreso Nacional de Historia del Arte (Multiculturalism in the Arts and Architecture: 16th National Art History Conference, Las Palmas, Anroart, 2006

- « El patrimonio documental de la Fábrica de Armas de Oviedo », Patrimonio industrial e historia militar: nuevos usos en el urbanismo y en la cultura (The Documentary Heritage of the Oviedo Arms Factory, Industrial Heritage and Military History: New Uses in Town Planning and Culture), Gijón, INCUNA, 2006

- « Patrimonio industrial, cultura, arte y sociedad. Propuestas y realidades » (Industrial Heritage, Culture, Art and Society. Proposals and Realities), Patrimonio industrial: Lugares de la memoria (Industrial heritage: Places of memory). Proyectos de reutilización en industrias culturales, turismo y museos (Reuse Projects in Cultural Industries, Tourism and Museums), Gijón, INCUNA, 2002

- « El patrimonio industrial asturiano: una valoración museística » (Asturias’ Industrial Heritage: a Museum Assessment), Arqueología industrial, patrimonio y turismo cultural (Industrial Archaeology, Heritage and Cultural Tourism), Gijón, INCUNA, 2001

- Arquitectura moderna en la central de Soto de Ribera: la obra de Ignacio Álvarez Castelao y Carlos Fernández Casado (Modern Architecture in the Soto de Ribera Power Plant: the Work of Ignacio Álvarez Castelao and Carlos Fernández Casado), Gijón, CICEES, 2009

- El salto de Grandas de Salime: arte e industria (Grandas de Salime Leap: Art and Industry) Gijón, 2007

\section{Minimal webography}

INCUNA: http://incuna.es/patrimonio-y-arqueologia-industrial/asturias/

Ábaco magazine: https://dialnet.unirioja.es/servlet/revista?codigo=3

Ería magazine: https://dialnet.unirioja.es/servlet/revista?codigo=509

Res Mobilis International research magazine on furniture and decorative objects: https:// dialnet.unirioja.es/servlet/revista?codigo=20042".

Ibero-american STS Magazine: http://www.revistacts.net/

CICEES Publishers: http://cicees.com/

La Catarata Publishers. "Science and Society Studies" collection: https://www.catarata.org/ coleccion/ensayos-ciencia-y-sociedad/ 


\section{ABSTRACTS}

The article proposes a course through scientific production on tangible and intangible industrial heritage in Asturias, one of the "classics" industrialization regions in contemporary Spain, and with a strongly attachment (but not exclusively) with the basic sectors of industry, particularly coal and steel. The work summarizes the main research paths, the historiographic trends and debates, and the latest roads in the interpretation of heritage right now.

L'article propose un parcours a travers la production scientifique sur le patrimoine industriel tangible et intangible dans les Asturies, une des régions d'industrialisation "classique » dans l'Espagne contemporaine, et avec un patrimoine fortement attaché (mais pas exclusivement) aux secteurs basiques de l'industrie, et notamment les charbonnages et la sidérurgie. Le travail résume les principaux parcours de recherche, les principaux débats historiographiques et les tendances en cours dans l'interprétation du patrimoine.

\section{INDEX}

Mots-clés: histoire des techniques, histoire des sciences, patrimoine industriel, historiographie, histoire socioculturelle du patrimoine, désindustrialisation, travail, risque

Subjects: Horizons internationaux

Keywords: history of technology, history of science, industrial heritage, historiography of technology and science, socio-cultural history of heritage, de-industrialisation

\section{AUTHOR}

\section{JORGE URÍA GONZÁLEZ}

Professeur d'histoire contemporaine à l'Université d'Oviedo (Espagne), Jorge Uría González dirige le Grupo de Investigación en Historia Sociocultural (GRUHSOC). 